ARTICLES

\title{
THE GOVERNANCE STRUCTURE OF SHADOW BANKING: RETHINKING ASSUMPTIONS ABOUT LIMITED LIABILITY
}

\author{
Steven L. Schwarcz*
}

\begin{abstract}
In an earlier article, I argued that shadow banking-the provision of financial services and products outside of the traditional banking system, and thus without the need for bank intermediation between capital markets and the users of funds-is so radically transforming finance that regulatory scholars need to rethink their basic assumptions. This Article attempts to rethink the corporate governance assumption that owners of firms should always have their liability limited to the capital they have invested. In the relatively small and decentralized firms that dominate shadow banking, equity investors tend to be active managers. Limited liability gives these investor-managers strong incentives to take risks that could generate outsized personal profits, even if that greatly increases systemic risk. For shadow banking firms subject to this conflict, limited liability should be redesigned to better align investor and societal interests.
\end{abstract}

\section{INTRODUCTION}

In a prior article, I argued that shadow banking is so radically transforming finance that regulatory scholars need to rethink their basic assumptions. ${ }^{1}$ In this Article, I argue that the governance structure of shadow banking

(C) 2014 Steven L. Schwarcz. Individuals and nonprofit institutions may reproduce and distribute copies of this Article in any format at or below cost, for educational purposes, so long as each copy identifies the author, provides a citation to the Notre Dame Law Review, and includes this provision in the copyright notice.

* Stanley A. Star Professor of Law \& Business, Duke University School of Law, and Founding Director, Duke Global Capital Markets Center; schwarcz@law.duke.edu. For helpful comments, I thank Brad Bernthal, Bill Brown, Anupam Chander, Peter ContiBrown, Andromachi Georgosouli, Erik Gerding, and Robert Hillman; participants in faculty workshops at University of California Davis School of Law, University of California Hastings College of Law, and University of Colorado School of Law; and participants at a public lecture at Queen Mary, University of London. I also thank Seth Bloomfield and Andres Rodriguez for valuable research assistance.

1 See Steven L. Schwarcz, Regulating Shadows: Financial Regulation and Responsibility Failure, 70 WASH. \& LeE L. REV. 1781 (2013). 
should be redesigned to make certain investors financially responsible, by reason of their ownership interests, for their firm's liabilities beyond the capital they have invested. ${ }^{2}$ This argument challenges the longstanding assumption of the optimality of limited liability.

Shadow banking is a loose term that refers to the decentralized provision of financing outside of traditional banking channels, and thus it is without the need for traditional modes of bank intermediation between capital markets and the users of funds. ${ }^{3}$ The shadow banking system is immense, recently estimated at sixty-seven trillion dollars worldwide. ${ }^{4}$ Numerous types of firms make up the shadow banking system. They include special purpose entities (SPEs), used in securitization and structured finance transactions to raise financing indirectly through the capital markets, ${ }^{5}$ as well as finance companies, hedge funds, money market mutual funds, nonbank governmentsponsored enterprises, securities lenders, and investment banks. ${ }^{6}$

Limited liability, this Article contends, is not always optimal for firms that make up the shadow banking system (hereinafter "shadow banking firms"). Limited liability can sometimes make the governance structure of these firms uniquely subject to a market failure that externalizes the systemic costs of taking a risky action. To repair this failure, managers of shadow

2 See, e.g., Black's Law Dictionary 426 (9th ed. 2009) (defining limited liability as the "liability of a company's owners for nothing more than the capital they have invested in the business").

3 See Fin. Stability Bd., Strengthening the Oversight and Regulation of Shadow BANKING 1 (2012), available at http://www.financialstabilityboard.org/publications/r_1204 20c.pdf (describing the shadow banking system as "credit intermediation involving entities and activities outside the regular banking system" (citation omitted)). Shadow banking is sometimes alternatively defined as the provision of financing by any type of financial intermediary that operates without access to central bank liquidity or public sector credit guarantees. Tobias Adrian \& Adam B. Ashcraft, Fed. Reserve Bank of N.Y., Staff Rep. No. 559, Shadow Banking Regulation 2 (2012). For additional background on shadow banking, see id.; Steven L. Schwarcz, Regulating Shadow Banking: Inaugural Address for the Inaugural Symposium of The Review of Banking E Financial Law, 31 Rev. Banking \& Fin. L. 619 (2012); Erik F. Gerding, The Shadow Banking System and Its Legal Origins (Jan. 24, 2012) (unpublished manuscript) (on file with author), available at http://ssrn.com/abstract=199 0816 .

4 Fin. Stability Bd., Global Shadow Banking Monitoring Report 3 (2012), available at http://www.financialstabilityboard.org/publications/r_121118c.pdf (estimating shadow banking's worldwide assets in 2011); $c f$. Zoltan Pozsar et al., Fed. Reserve Bank of N.Y., Staff ReP. No. 458, Shadow Banking 4-5 (rev. 2012), http://www.newyorkfed .org/research/staff_reports/sr458.pdf (arguing that shadow bank financing appears to dwarf traditional bank financing).

5 See Schwarcz, supra note 3, at 621. These SPEs include asset-backed commercial paper (ABCP), conduits, and structured investment vehicles (commonly known as "SIVs"). Id.

6 Banks themselves can be regarded as shadow banking firms to the extent they facilitate customer financing in an agency capacity, as opposed to making loans or otherwise extending credit to their customers. For example, banks often create SPEs, ABCP conduits, and SIVs. Banks also are important players in repo markets. Id. at 621-22. 
banking firms should sometimes be required to put more "skin in the game," in order to better align incentives ${ }^{7}$ between their firms and society. ${ }^{8}$

This Article proceeds as follows: In Part I, the Article sets forth the background for its analysis, including a short history of how corporate limited liability became the norm and an overview of the general academic debate on whether it should be the norm. In Part II, the Article analyzes whether limited liability should be the norm for the governance structure of shadow banking. The Article starts that analysis by proposing a normative framework for rethinking the corporate governance assumptions about limited liability. It then applies that framework to shadow banking. Although limited liability has always been a potential source of externalities, the Article finds that it is a uniquely fertile source of systemic externalities for shadow banking firms, and that current law does not-nor are adaptations to traditional legal remedies likely to-adequately internalize those externalities. To mitigate those externalities, limited liability should be redesigned for shadow banking firms that are governed by conflicted investor-managers. Part III of the Article explores how limited liability could be redesigned, establishing goals for the redesign and testing redesign proposals against those goals. Annex I to the Article provides practical guidance for assessing the costs and benefits of any particular redesign.

This Article does not directly engage whether-or the extent to whichshadow banking should be subject to substantive capital and solvency regulation, or even prohibited. As to the first, it has not historically been customary, at least in the United States, to engage in solvency regulation of firms that are not traditional banks. ${ }^{9}$ The Dodd-Frank Act is beginning to change that, with its regulation of certain systemically important financial institutions. ${ }^{10}$ Nonetheless, even though the limited-liability rule of corporation law can cause externalities, the government does not generally "take a more active role in assuring the solvency of corporations." 11 In part, this is because government micromanagement of the private sector is not always efficient. ${ }^{12}$ Likewise, it might well be unwise to attempt to prohibit shadow banking. Even if that were feasible, shadow banking "has the potential to create both benefit and harm. Empirically, we do not yet know which effect is likely to

7 Cf. Eugene N. White, Rethinking the Regulation of Banking: Choices or Incentives? 2 (Dec. 6, 2011) (unpublished manuscript) (on file with author) (arguing that bank regulatory "reform should focus on changing the incentives that parties face to insure that they are correctly aligned to induce the development of less fragile institutions").

8 See Schwarcz, supra note 3, at 635-36. This Article does not argue that such managers necessarily have conflicts with their firms. I have separately argued, however, that certain managers, especially secondary or middle managers, may well have such conflicts. See Steven L. Schwarcz, Conflicts and Financial Collapse: The Problem of Secondary-Management Agency Costs, 26 Yale J. on Reg. 457, 458-59 (2009).

9 See Richard A. Posner, Economic Analysis of Law 413-14 (6th ed. 2003).

10 See infra note 124 and accompanying text.

11 Posner, supra note 9, at 413.

12 Id. at 413-14 (describing the "continuous regulatory scrutiny" of an agency as a "statist" solution with only "arguabl[y]" positive benefits). 
dominate."13 Therefore, "financial regulation of shadow banking should . . strive to examine ... how to mitigate the potential harm while preserving the potential benefit."14 That is this Article's goal.

\section{BACKGROUND}

As background for this Article's analysis of limited liability in the context of shadow banking, the discussion begins by examining, from a historical standpoint, how corporate limited liability became the general norm and then, from a scholarly standpoint, whether it should be the general norm.

\section{A. History of Limited Liability}

Limited liability has been called "a distinguishing feature of corporate law-perhaps the distinguishing feature" of corporate law. ${ }^{15}$ Yet early corporations did not have limited liability. Because their histories are different, first consider the evolution of limited liability for shareholders of nonbank corporations, then consider that evolution for shareholders of banks. Finally, compare these with the evolution of limited liability outside the United States.

\section{Nonbank Corporations}

During the early nineteenth century, for example, unlimited shareholder liability was the norm. ${ }^{16}$ The rationale for such unlimited liability was that creditors assured of repayment from shareholders would lend the corporation additional capital. ${ }^{17}$ Indirect shareholder liability, which resulted from the corporate power to make assessments, was also a common feature of early nineteenth-century corporations. ${ }^{18}$

13 Steven L. Schwarcz, Framing Address: A Framework for Analyzing Financial Market Transformation, 36 Seattle U. L. Rev. 299, 305 (2013).

$14 I d$.

15 See Frank H. Easterbrook \& Daniel R. Fischel, The Economic Structure of CorPORATE LAW 40 (1991).

16 Corporate charters in Connecticut, New Hampshire, Vermont, and New York all provided for direct and unlimited shareholder liability. See Phillip I. Blumberg, Limited Liability and Corporate Groups, 11 J. CoRP. L. 573, 588 (1986). Corporate charters in Maine, Massachusetts, and Rhode Island contained an express provision that shareholders would be fully liable. Nina A. Mendelson, A Control-Based Approach to Shareholder Liability for Corporate Torts, 102 Colum. L. REv. 1203, 1209-10 (2002). Even with the rise of manufacturing companies in New England states, early corporate charters and statutes imposed direct liability on shareholders. Blumberg, supra, at 591. For a discussion of the historical foundations of limited liability prior to the nineteenth century, see Robert W. Hillman, New Forms and New Balances: Organizing the External Relations of the Unincorporated Firm, 54 WASH. \& LeE L. Rev. 613 (1997).

17 Mendelson, supra note 16 , at 1210.

18 See Blumberg, supra note 16, at 590-91; E. Merrick Dodd, The Evolution of Limited Liability in American Industry: Massachusetts, 61 Harv. L. Rev. 1351, 1356-57 (1948). 
Legislators initially were willing to allow corporations performing public functions, such as operating turnpikes, toll bridges, and canals, to organize under corporate charters with limited shareholder liability. ${ }^{19}$ But they were unwilling to permit limited liability for shareholders of manufacturing corporations. $^{20}$ The movement toward general limited liability started in the courts when judges had to determine "whether shareholders were directly liable for corporate debts if the [corporate] charter was silent on shareholder liability."21

By the mid-nineteenth century, most courts "presum[ed] limited shareholder liability in the absence of any legislative rule."22 Different courts had different rationales. Some courts, for example, reasoned that because some corporate charters contained express statements imposing direct liability, the absence of those statements in a charter implied an intent not to impose such liability. ${ }^{23}$ Other courts wanted to avoid an injustice to shareholders who were both innocent and ignorant of a corporation's mismanagement. ${ }^{24}$ Federal courts often relied on a trust fund theory: shareholders are merely residuary owners, reimbursed only after the corporation pays its debts; ${ }^{25}$ thus a corporation is like a trust fund in which the capital stock is used for the payment of corporate debts while stockholders are liable only for the amount of capital stock they contribute. ${ }^{26}$

Around the same time, legislatures began allowing limited liability, even for shareholders of manufacturing corporations. ${ }^{27}$ This change appears to

19 Blumberg, supra note 16, at 593; Dodd, supra note 18, at 1352.

20 Not only were legislators initially reluctant to grant corporate charters with limited liability to manufacturing corporations, they were generally reluctant to grant any corporate charters to manufacturing corporations until 1809. Blumberg, supra note 16, at 590-91; Dodd, supra note 18, at 1352-55.

21 Blumberg, supra note 16, at 591.

22 Mendelson, supra note 16, at 1210 n.17 (quoting Morton J. Horowitz, The TransFORMATION OF AMERICAN LAW, 1870-1960, at 94 (1992)). Massachusetts courts as early as 1808 and Pennsylvania courts by 1816, for example, held that shareholders, absent an express provision in the charter or in a statute, were not directly liable for corporate debts. Blumberg, supra note 16, at 592. Federal courts, by 1824, similarly recognized limited liability for corporate shareholders as the default rule. Id.

23 Mendelson, supra note 16, at 1210 n.17.

24 Spear v. Grant, 16 Mass. (1 Tyng) 9, 14 (1819) ("[I]f [a stockholder] were equally liable to each holder of the notes (which he must be if liable at all; for if the facts agreed create a promise to one, they create a promise to all), then the most palpable injustice would take place. For a stockholder, wholly innocent and ignorant of the mismanagement, which has brought the bank into discredit, might be ruined by reason of owning a single share in the stock of the corporation.").

25 Wood v. Dummer, 30 F. Cas. 435, 436 (C.C.D. Me. 1824) (No. 17,944).

26 Id. at $436-37$.

27 Blumberg, supra note 16, at 592. New York and New Jersey began allowing limited liability for shareholders of manufacturing corporations, followed in 1823 by New Hampshire, Connecticut, and Maine. Id. at 593, 599-600. Massachusetts, in 1830, and Rhode Island, in 1847 , were slower to adopt limited liability for manufacturing corporations. Id. at 593 . 
have been more driven by pragmatic factors. In part, it was responsive to the increasing political influence of industrialists, resulting from the rapid growth of the manufacturing industry. ${ }^{28}$ In part, it was responsive to a "flight-of-capital argument" that states failing to legislate limited shareholder liability would suffer a flight of corporate capital to other states that had limited liability. ${ }^{29}$

Limited liability did not become universal in the United States, however, until a century later. California, for example, imposed pro rata shareholder liability for all corporate debts and obligations until 1931. ${ }^{30}$ This pro rata liability did not appear to cause a flight of corporate capital to other states or otherwise impede California's economic growth. ${ }^{31}$

\section{Banks}

Unlike nonbank corporations in which shareholders initially were subject to unlimited liability, bank shareholders initially were subject to (only) double liability-liability for corporate obligations in an amount equal to the par value of their shares. ${ }^{32}$ States imposed double liability either by express provisions in state bank charters or in their state constitutions. ${ }^{33}$ Congress followed the example of the states and provided for double liability in the National Banking Act of 1863. ${ }^{34}$ According to the senator who proposed the provision, its purpose was to provide additional protection to bank creditors and, in effect, to also prevent the bank from engaging in excessively risky operations. ${ }^{35}$

28 Id. at 592-93.

29 Dodd, supra note 18, at 1367-68, 1369. There were other, lesser, factors. In Massachusetts, for example, the governor feared that unlimited liability made shares of Massachusetts manufacturing corporations nearly worthless, and therefore brought financial ruin to Massachusetts's families. Id. at 1368. A Massachusetts senator also argued that unlimited liability created a moral hazard problem by enabling manufacturing corporations to obtain credit in an amount in excess of the value of their business assets. Id. at 1370 .

30 Blumberg, supra note 16 , at 597.

31 Id. at 599; see also Henry Hansmann \& Reinier Kraakman, Toward Unlimited Shareholder Liability for Corporate Torts, 100 YALE L.J. 1879, 1924 (1991) (noting that California imposed unlimited, pro rata liability by statute on shareholders, "evidently without crippling industrial and commercial development").

32 Jonathan R. Macey \& Geoffrey P. Miller, Double Liability of Bank Shareholders: History and Implications, 27 WAKe Forest L. Rev. 31, 36 (1992).

$33 I d$.

34 Id. The National Banking Act of 1863 specifically provided that "each shareholder shall be liable to the amount, at their par value, of the shares held by him in addition to the amount invested in such shares." National Banking Act of 1863, ch. 58, 12 Stat. 665, 668. The senator who proposed the provision explicitly recognized that the provision "tracked the laws of 'most of the States of the Union.' Macey \& Miller, supra note 32, at 36 (citing Cong. Globe, 37th Cong., 3d Sess. 824 (1863)).

35 Macey \& Miller, supra note 32, at 36 (citing Cong. GLobe, 38th Cong., 1st Sess. 1869 (1864)). 
Double liability for bank shareholders quickly fell out of favor, however, following the Great Depression. Several factors contributed to its rapid fall from grace, ${ }^{36}$ including a perception of unfairness caused by liability of bank shareholders who did not contribute to management decisions ${ }^{37}$ and public questioning of its ability to reduce risk given the widespread bank failures. ${ }^{38}$ In response, Congress ended double liability for shareholders of national banks and states ended double liability for shareholders of state-chartered banks. ${ }^{39}$ Today, "double liability for bank shareholders is a dead letter everywhere." 40

Limited liability is now the general default rule in the United States for shareholders of banks and nonbank corporations. ${ }^{41}$ As explained below, the United States is not alone in adopting limited liability.

\section{Limited Liability's Development in Foreign Jurisdictions}

Civil law countries in Europe adopted limited liability even earlier than the United States. ${ }^{42}$ Canada $^{43}$ and England ${ }^{44}$ adopted limited liability after the United States.

$36 \quad$ Id. at 37.

37 Id. One commentator remarked that double liability "disappeared in the wake of the Great Depression where shareholders, who were hit by the huge unanticipated losses, pleaded with federal and state legislators to move to single liability." White, supra note 7 , at 8 . The public's disgust with double liability during this time is exemplified by the popular press's harsh criticism of the Supreme Court in 1944 for upholding an assessment of shareholders of a holding company for the liabilities of a failed subsidiary bank. Macey \& Miller, supra note 32 , at 37-38.

38 See Macey \& Miller, supra note 32, at 38.

39 Id. at 38-39 ("In 1933, Congress repealed double liability for newly-issued national bank shares; and in 1935, it prospectively extinguished all double liability for national bank stock provided that a bank gave six months notice of termination." (footnote omitted)); see Blumberg, supra note 16, at 601 (noting actions by Congress and state legislatures that ended double liability for shareholders of national and state banks).

40 Macey \& Miller, supra note 32, at 39.

41 According to Section 6.22 of the Model Business Corporation Act, a shareholder is "not personally liable for the acts or debts of the corporation except that he may become personally liable by reason of his own acts or conduct." Model Bus. Corp. Act $§ 6.22$ (b) (2002); see Mendelson, supra note 16, at $1211 \mathrm{n} .25$ (detailing the adoption of limited liability provisions in several states). Most states have adopted alternative corporate forms such as the Limited Liability Corporation (LLC) and the Limited Liability Partnership (LLP), which also provide equity owners with limited liability for corporate debts and obligations. See id. at 1209 n.14. For further discussion of the development of the LLC corporate form both in the United States and in foreign jurisdictions, see, e.g., Franklin A. Gevurtz, BusiNess Planning 64 (4th ed. 2008); Franklin A. Gevurtz, The Globalization of Corporate Law: The End of History or a Never-Ending Story?, 86 WASH. L. REv. 475, 487 (2011); Marcus Lutter, Limited Liability Companies and Private Companies, in 13 InTERNATIONAL ENCYClopedia of Comparative Law, ch. 2, at 4-6 (Detlev Vagts ed., 1998).

42 See Blumberg, supra note 16, at 596 (discussing France's experience as early as 1807 with limited liability, and how limited liability then spread throughout Europe).

43 Id. at 594 (discussing Canada's adoption of limited liability in 1850).

$44 I d$. at 584 (discussing England's adoption of limited liability in 1855). 
The move towards limited liability in England is instructive. Joint stock associations, in which members were liable for association debts, were the dominant form of business organization during the early nineteenth century, because corporate charters were difficult and expensive to obtain. ${ }^{45} \mathrm{Mem}$ bers attempted in various ways to limit their liability, including by inserting the term "limited" in the association's name. ${ }^{46}$ At least partly in response, Parliament passed a law facilitating general incorporation but imposing unlimited liability on shareholders with rights of contribution from fellow shareholders. ${ }^{47}$ That law also prohibited the corporate charter from limiting liability. ${ }^{48}$

Wealthy investors were outraged, being concerned "that creditors would first proceed against them in preference to less wealthy members." 49 They sparked a political debate, arguing that the law would inhibit investment. ${ }^{50}$ As a result, Parliament first enacted limited liability for investors in railwaysthen one of England's most successful and growing industries. ${ }^{51}$ That soon led to a legislative broadening of limited liability, not only for shareholders of new corporations generally but also for members of new and existing joint stock associations. ${ }^{52}$ Shortly thereafter, limited liability was extended to shareholders of banks ${ }^{53}$ and insurance companies. ${ }^{54}$

\section{How History Informs the Limited Liability Debate}

The historical trend towards limited liability can help to inform the debate. In the United States and England, the legislative trend was heavily influenced by lobbying. In the United States, the legislative trend was also influenced (in a nonbank context) by fear of capital flight to other states. ${ }^{55}$

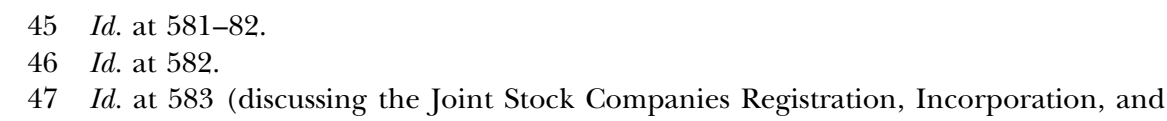
Regulation Act, 1844).

$48 I d$. (observing also that the law was silent as to whether contracts with third parties could limit shareholder liability).

$49 \quad I d$.

$50 \quad I d$.

$51 \quad I d$. at 584.

$52 I d$. (discussing the Limited Liability Act, 1855 and the Joint Stock Companies Act, 1856).

53 Id. (discussing legislation in 1857 and 1858).

54 Id. (discussing legislation in 1862).

55 Subsequent experience suggests, however, that unlimited liability may not necessarily cause capital flight. See supra notes 30-31 and accompanying text (observing that California's pro rata liability rule did not appear to cause a flight of corporate capital to other states); see also Blumberg, supra note 16, at 594 ("In fact, there is little sign that the different legal rules on shareholder liability adversely affected economic development in Massachusetts and Rhode Island during this period."); Dodd, supra note 18, at 1378 ("There is some indication that the early adoption of the limited-liability principle by New Hampshire and Connecticut stimulated the development of the cotton-textile industry in those states. Yet both states continued to lag, as producers of cotton textiles, behind Massachusetts, 
The judicial progression towards limited liability has more of a "fairness" rationale: to protect innocent shareholders who are not in a "capacity to control" or influence management decisions. ${ }^{56}$ This rationale is also part of the justification for shifting from bank-shareholder double liability to limited liability: imposing double liability on bank shareholders who did not contribute to management decisions created a perception of unfairness. ${ }^{57}$

The shift from bank-shareholder double liability to limited liability also reflected disappointment that double liability did not prevent the bank failures of the Great Depression. The magnitude of the Great Depression, however, does not make it an appropriate test; its impact overwhelmed even many prudent banks. ${ }^{58}$

The historical trend in England towards limited liability likewise can help to inform the debate. The turning point was opposition to unlimited liability by wealthy investors, who feared they would become the ultimate deep pockets for their firms' liabilities. ${ }^{59}$ It is unclear, though, whether fully limiting liability was the only way to remove the fear, thereby ensuring investment. Without totally sacrificing the monitoring benefits of shareholder liability, that fear could have been mitigated by partially limiting shareholder liability, such as to double liability or pro rata liability. ${ }^{60}$

\section{B. The General Academic Debate}

Next consider the academic debate on whether limited liability should generally be the norm. To that end, the discussion below reviews scholarly challenges to limited liability made prior, and then in response, to the global financial crisis, ${ }^{61}$ and then compares those challenges with scholarly justifications for limited liability.

which did not adopt the principle until 1830, and Rhode Island, which did not adopt it until seventeen years later." (footnotes omitted)).

56 See supra note 24 and accompanying text.

57 See supra notes $36-37$ and accompanying text. At least some bank shareholders were also bank insiders, however. Macey \& Miller, supra note 32, at 56.

58 A positive result of the double liability regime was that it encouraged prudent bank practices including voluntary liquidation of failing banks. Macey \& Miller, supra note 32, at 57. Notably, however, involuntary liquidations approached the number of voluntary liquidations and consolidations during the difficult years of 1929-1933. Id. at 58.

59 See supra note 49 and accompanying text.

60 Professor Gerding also argues that the historical trend in England towards limited liability followed a pattern - an expansion of limited liability and liberalization of corporate law rules, followed by a financial boom, then followed by a financial bust-that proceeded like clockwork every ten years from 1825 through the nineteenth century. ERIK F. Gerding, Law, Bubbles, and Financial Regulation 74-77 (2013).

61 By "global financial crisis," this Article means the financial crisis of 2007-2008. 


\section{Scholarly Challenges Prior to the Global Financial Crisis}

Scholarly challenges to limited liability initially focused on harm caused by corporate torts. ${ }^{62}$ The concern was that limited liability created moral hazard $^{63}$ : shareholders whose liability was capped at the value of their equity contribution would want their firms to engage in riskier-and therefore more tort-prone-projects than is socially optimal. ${ }^{64}$

To mitigate this suboptimal risk-taking, some scholars advocated pro rata, unlimited shareholder liability; ${ }^{65}$ others advocated a control-based liability regime. ${ }^{66}$ Under the former, shareholders would be liable for unpaid tort judgments in proportion to their equity ownership of the firm. ${ }^{67}$ Under the latter regime, only shareholders with a "capacity to control" 68 their firms would be liable for tort judgments. ${ }^{69}$

Scholars also challenged the limited liability of bank shareholders, arguing for a return to double liability. ${ }^{70}$ Professors Macey and Miller used historical data on bank failures ${ }^{71}$ to argue that banks whose shareholders are

62 See Hansmann \& Kraakman, supra note 31, at 1879-80 (briefly introducing the existing scholarship proposing to curtail limited liability).

63 Id. at 1882.

64 Mendelson, supra note 16, at 1232-33. I have previously considered an analogous problem- "marginalizing" risk in debt markets. Investors follow the conventional wisdom of risk dispersion-they diversify their investment portfolios to reduce risk. Risk dispersion, however, can lead investors to both underestimate and underprotect against risk due to market failures including information failure, model failure, human processing failure, and collective action failure. This "marginalization" of risk can result in harm to the actual market participants and harm that extends beyond the market participants, such as financial crisis or systemic collapse. See Steven L. Schwarcz, Marginalizing Risk, 89 WASH. U. L. Rev. 487 (2012).

65 Hansmann \& Kraakman, supra note 31, at 1892-1909.

66 Mendelson, supra note 16, at 1271-1301.

67 Hansmann \& Kraakman, supra note 31, at 1892; see id. at 1906-09 (arguing that pro rata liability would marginally increase shareholders' incentives to monitor and help avoid their firm's risky activities).

68 A shareholder with the "capacity to control" is a shareholder with a controlling ownership stake in the corporation. Mendelson, supra note 16, at 1271 n.281. These shareholders are uniquely positioned with low-cost access to corporate information and are better able to influence corporate decisions. Id. at 1249-52. Corporations that have a shareholder with the "capacity to control" are more likely to engage in excessively risky activities. See id. at 1258 (explaining that shareholders with the "capacity to control" are more attracted to hazardous activities with small risk of large loss and better able to influence the corporation to engage in these activities). Consequently, "under limited liability, there is a set of risky activities that a company with a dispersed share ownership would not select, but a company with a controlling shareholder would." Id.

69 Id. at 1271; see id. at 1272-79 (detailing the logistics of a control-based liability regime).

70 See supra text accompanying note 32 . Recall that double liability meant shareholder liability for obligations in an amount equal to the par value of their shares.

71 Macey and Miller scrutinized the recovery rate of national bank assessments, the liquidation of national banks, the average annual losses from national bank failures, and bank capital ratios. Macey \& Miller, supra note 32, at 55-61. 
subject to double liability may fail less frequently than banks whose shareholders have limited liability. ${ }^{72}$ Professor Grossman, an economist, also used historical data to conclude that double liability generally had the effect of reducing risk-taking. ${ }^{73}$ These studies countered the dubious narrative that because double liability failed to guarantee bank stability during the Great Depression, it does not reduce risk-taking. ${ }^{74}$

\section{Scholarly Challenges After the Global Financial Crisis}

In response to the global financial crisis, scholars have revisited the limited liability debate, focusing on moral hazard as a cause of excessive risktaking in the financial industry. Professor White, an economist, posits that the crisis resulted from the "steady erosion of incentives that induced management to control risk," including investment banks' shift from partnerships with unlimited liability to corporations with limited liability. ${ }^{75}$ Professors Hill and Painter have independently made and developed similar arguments. ${ }^{76}$ Other scholars, such as Peter Conti-Brown, have echoed these arguments, focusing on the impact of the risk-taking: shareholders protected by limited liability can "pocket the benefits generated by [their firms'] risky activities,"

$72 I d$. at 32. Immediately following the Great Depression, conventional wisdom was that double liability failed to adequately protect bank creditors and therefore the system needed to be replaced by deposit insurance to better protect bank creditors. See supra notes 36-40 and accompanying text. Macey and Miller, however, concluded that double liability was a successful mechanism for protecting bank creditors and promoting sound banking practices because recoveries from shareholders were good-the recovery rate during this period was approximately fifty-one percent; banks were encouraged to privately transfer assets before failure; banks were encouraged to more cautiously manage assets to avoid shareholder assessment; and banks were allowed to operate with lower capital ratios. Macey \& Miller, supra note 32, at 56, 61-62.

73 Richard S. Grossman, Double Liability and Bank Risk Taking, 33 J. Money, Credit \& BANKING 143, 157 (2001) ("The effects of double liability can be seen through lower failure rates, higher capital ratios, and higher liquidity ratios among state banks in multiple-liability states.”). Professor Grossman examined state-level failure data on state and national banks, state-level balance sheet data for state and national banks, and data on individual state and national banks in Alabama and Mississippi prior to and following the introduction of double liability in Mississippi. Id. at 147.

$74 I d$. at 157-58. Grossman also examined empirical data to understand the motivations for legislating double liability or limited liability. Richard S. Grossman, Fear and Greed: The Evolution of Double Liability in American Banking, 1865-1930, 44 Explorations ECON. Hist. 59, 59 (2007). States legislating double liability were motivated by fear; they wanted to deter high levels of bank failures by motivating sounder banking practices. Id. at 71-75. States legislating limited liability were motivated by greed; they wanted to encourage growth through increased bank investment and risk-taking. Id.

75 White, supra note 7, at 2-3. White suggests that double liability for banks reflected a "superior alignment of liabilities and incentives for shareholders and managers so that the risk-taking temptations of managers were controlled.” Id. at 4-6 (supporting this conclusion with numerical examples to demonstrate that the system of double liability incentivized shareholders, senior bank management, and directors to control and reduce risktaking).

76 See infra notes 80-84 and accompanying text. 
while the costs of those risky activities is passed on to the government through bailouts and ultimately onto taxpayers. ${ }^{77}$

These arguments effectively continue the pre-crisis observation that limited liability theoretically incentivizes risky action. ${ }^{78}$ The investment-banking example of the shift from unlimited to limited liability also helps to concretize this observation. ${ }^{79}$ Prior to 1970 , investment banks were organized as partnerships, with partners facing personal liability for the debts of their firm if it failed. ${ }^{80}$ This restrained risk-taking. ${ }^{81}$ Following a change to the New York Stock Exchange rules allowing brokerage firms to have publicly owned

77 Peter Conti-Brown, Elective Shareholder Liability, 64 Stan. L. Rev. 409, 411-12 (2012). Despite their seemingly unfair consequences, bailouts are in many cases necessary to prevent complete financial collapse. Id. at 412. The U.S. government, for example, bailed out American International Group, Inc. (AIG) because of the fear that if AIG had been allowed to fail it would have resulted in "a domino effect of failures reaching around the world.” See generally William K. Sjostrom, Jr., The AIG Bailout, 66 WASH. \& LeE L. Rev. 943, 978 (2009) (discussing the AIG bailout). Conti-Brown proposes modifying limited liability under an "elective shareholder liability" rule: firms can elect between larger capital adequacy requirements or pro rata shareholder liability in the case of a bailout. Conti-Brown, supra, at 429-34.

78 Anat R. Admati \& Paul Pfleiderer, Increased-Liability Equity: A Proposal to Improve Capital Regulation of Large Financial Institutions 4 (Rock Ctr. for Corporate Governance, Working Paper No. 68, 2010; Stanford Univ. Graduate Sch. of Bus., Research Paper No. 2043, 2010). Generally, a firm's directors owe a fiduciary duty to shareholders and not to creditors. In a limited context, however, a firm's directors may owe a fiduciary duty to creditors-when the firm is in the vicinity of insolvency. There is, however, no hard and fast rule on which a director can rely. Therefore, it is unclear how a director should balance between protecting creditors and encouraging a corporation to innovate and take appropriate business risks. In practice, corporations take more risks to fulfill their duty to shareholders and ultimately shift the risk on to creditors. See Credit Lyonnais Bank Nederland, N.V. v. Pathe Commc'ns Corp., Civ. A. No. 12150, 1991 WL 277613 (Del. Ch. Dec. 30, 1991); Steven L. Schwarcz, Structured Finance, A Guide to The Principles Of Asset Securitization § 3:2.1 (3d ed. 2002 \& Supp. 2006).

79 Notwithstanding this observation, some scholars have argued that debt creates incentives that impose discipline on a firm's managers. See Anat R. Admati et al., Liability Holding Companies, 59 UCLA L. REv. 852, 857-58 (2012) (discussing the argument that debt funding helps to reduce agency costs by imposing discipline on corporate managers). Covenants are a central mechanism used by creditors for limiting a firm's ability to take excessive risks and monitoring a firm's management. See generally Michael C. Jensen \& William H. Meckling, Theory of the Firm: Managerial Behavior, Agency Costs and Ownership Structure, 3 J. Fin. Econ. 305, 337-39 (1976); George G. Triantis \& Ronald J. Daniels, The Role of Debt in Interactive Corporate Governance, 83 Calif. L. REv. 1073, 1074 (1995). Other scholars have noted, however, that this is inapplicable to banks. Admati et al., supra, at 858. Bank debt, backed by deposit insurance and implicit government guarantees, fails to incentivize creditors to monitor bank management because creditors expect to recover even if the bank fails. Id. This exacerbates the moral hazard problem because the government and ultimately taxpayers bear the downside risks. Admati \& Pfleiderer, supra note 78 , at 4 .

80 Claire Hill \& Richard Painter, Berle's Vision Beyond Shareholder Interests: Why Investment Bankers Should Have (Some) Personal Liability, 33 Seattle U. L. Rev. 1173, 1177-79 (2010).

81 Id. at 1179. 
shares, investment banks switched to the corporate form. ${ }^{82}$ Because investment bankers were now protected by limited liability, "frenetic risk-taking [allegedly] became the norm." 83 Professors Hill and Painter liken this to gambling with "house money," in which the investment bankers have no personal stake. ${ }^{84}$

\section{Scholarly Justifications for Limited Liability}

Next compare these scholarly challenges to limited liability with the scholarly justifications for limited liability. The traditional scholarly justification for limited liability is the encouragement of equity-capital investment. ${ }^{85}$ This so-called "efficiency justification" 86 holds that limited liability creates appropriate incentives for widespread investor participation in equity ownership, especially in large corporations. ${ }^{87}$ Besides addressing investor risk aversion, ${ }^{88}$ limited liability reduces monitoring costs: an equity investor need not overly worry about monitoring the firm's risky actions (for which the investor could ultimately become liable), ${ }^{89}$ nor need an equity investor worry about monitoring the wealth of other shareholders (for whose shareholder liability the investor could ultimately bear under a joint-and-several shareholder liability regime, which could be especially tricky given the free transferability of equity shares). ${ }^{90}$ Additionally, by promoting the free transfer of shares, ${ }^{91}$

82 Id. at 1181.

83 Id. at 1181-82.

84 Id. at 1183-84. An additional consequence of limited liability is that investment bankers are less concerned with the absolute amount of money at risk. For example, " $\mathrm{t}]$ he possibility of a loss of $\$ 950$ million of a $\$ 1$ billion portfolio, having $\$ 50$ million left over, may matter less than the possibility of a loss of all but $\$ 1$ million of just about any large portfolio." Id. at 1185 .

85 Janet Cooper Alexander, Unlimited Shareholder Liability Through a Procedural Lens, 106 Harv. L. Rev. 387, 390 (1992).

86 The moniker "efficiency justification" arose because limited liability is said to encourage an efficient level of investment. Mendelson, supra note 16, at 1217.

87 Blumberg, supra note 16, at 612-13.

88 See Mendelson, supra note 16, at 1218-19 (discussing arguments as to how limited liability corrects excessive investor risk aversion). Scholars have argued that limited liability allows shareholders to diversify their investments and consequently encourages shareholder risk-taking. Under limited liability, no one investment will expose all of the shareholder's assets to risk. Therefore, a shareholder can invest in a diversified portfolio of varying risk where each investment's ultimate risk is limited to the amount of capital invested. Blumberg, supra note 16, at 616; Frank H. Easterbrook \& Daniel R. Fischel, Limited Liability and the Corporation, 52 U. CHI. L. REv. 89, 96-97 (1985); Larry E. Ribstein, Limited Liability and Theories of the Corporation, 50 Mo. L. REv. 80, 102 (1991). In the absence of these diversification benefits, some projects with positive net present values would be rejected as "too risky." Easterbrook \& Fischel, supra, at 97.

89 Blumberg, supra note 16, at 614; Easterbrook \& Fischel, supra note 88, at 94-95; Ribstein, supra note 88, at 103.

90 Blumberg, supra note 16, at 614-15; Easterbrook \& Fischel, supra note 88, at 95. Limited liability also contributes to uniformity in share price. Without limited liability, investors would attach different values to shares, depending on that investor's wealth. 
limited liability serves to create incentives for managers to act efficiently: shareholders can transfer their shares if managers perform poorly, and the new shareholders can install new managers. ${ }^{92}$

\section{How Existing Scholarship Informs the Limited Liability Debate}

The existing scholarship recognizes that limited liability can create moral hazard, leading to excessive corporate risk-taking. On balance, though, limited liability encourages equity-capital investment by addressing investor risk aversion and by reducing investor monitoring costs. It also may create incentives for managers to act efficiently.

The existing scholarship does not examine limited liability in the context of the emerging shadow banking system. Even the scholarship that uses investment banks as an example does not purport to analyze how investment banks - which can be viewed as a type of shadow bank ${ }^{93}$ - might or might not be generally representative of shadow banking firms. ${ }^{94}$ This Article next analyzes limited liability in the shadow banking context.

\section{ANAlysis}

Should limited liability be the norm for the governance structure of shadow banking? To answer that question, this Article begins by deriving a normative framework for rethinking the corporate governance assumptions about limited liability. Thereafter, the Article applies that framework to shadow banking.

Therefore, limited liability, by removing a shareholder's individual wealth from contemplation of liability, results in homogenous shares with a single market price. See Easterbrook \& Fischel, supra note 88, at 92; Paul Halpern et al., An Economic Analysis of Limited Liability in Corporation Law, 30 U. ToRonto L.J. 117, 147 (1980).

91 Easterbrook \& Fischel, supra note 88, at 95 . Limited liability promotes the free transfer of shares because, as discussed supra note 90 and accompanying text, the costs of monitoring other shareholders are reduced, simultaneously reducing the cost of transferring shares to a new shareholder.

92 Easterbrook \& Fischel, supra note 88, at 95. Easterbrook and Fischel also argue that legislative-imposed limited liability is more efficient than legislative-permitted limited liability because contracting around liability would be cost prohibitive, thereby discouraging capital investment. Id. at 93. Accordingly, limited liability effectively "creates an efficient contract term applicable to all transactions." Blumberg, supra note 16, at 615-16.

93 See supra text accompanying notes 5-6.

94 Hill and Painter focus on investment banking but nonetheless define the firms they discuss as "most firms that are federally insured banks or bank holding companies; firms that originate, buy, or sell mortgages; firms registered as broker-dealers or investment advisors under the Securities Exchange Act; and at least the larger hedge funds." Hill \& Painter, supra note 80 , at 1190 . Although this definition would, in part, cover the shadow banking system, their article lacks analysis as to whether investment banks might or might not be generally representative of shadow banking firms. 


\section{A. Deriving a Normative Framework}

Any attempt to rethink assumptions relating to corporate governance should situate that inquiry within a normative framework. Because corporate governance rules are a subset of financial regulation, ${ }^{95}$ that inquiry should be situated within a financial regulatory framework. The central purpose of financial regulation is correcting market failures. ${ }^{96}$

Of the five general categories of market failures, three are potentially relevant to corporate governance: information failure, agency failure, and externalities (externalizing harm onto third parties). ${ }^{97}$ In the shadow banking system, the third market failure-externalities-becomes much more important. That is because the paramount concern posed by the shadow banking system is that it "can, if left unregulated, pose systemic risks to the financial system." 98 Systemic risks, in turn, can cause massive harm to the real economy. ${ }^{99}$

In discussing the third market failure, I have argued, however, that "externalities" is a misleading term because it conflates cause and effect. Externalities are not the cause but, instead, the consequences of a failure. ${ }^{100}$

95 Cf. Corporate Governance and the New Financial Regulation: Complements or Substitutes?, Res. Newsl. (Eur. Corp. Governance Inst., Brussels, Belg.), Spring 2011 (discussing the relationship between corporate governance and financial regulation).

96 See, e.g., David Gowland, The Regulation of Financial Markets in the 1990s 21 (1990) (" $[R]$ egulation can be beneficial if and only if there would otherwise be market failure."). Welfare economists argue that regulation should also include the goal of maximizing social welfare. See, e.g., Charles Wolf, Jr., A Theory of Nonmarket Failure: Framework for Implementation Analysis, 22 J.L. \& EcON. 107, 110-11 (1979) (noting that, from the perspective of welfare economists, "it is theoretically correct to consider distributional inequity as an example of market failure").

97 The other two traditional market-failure categories-monopolies and other types of non-competitive markets, and the public goods problem (a form of collective action problem describing the inability of markets to provide goods that, like clean air, are nonexcludable and non-rivalrous, since some parties will want to free ride on public goods when such goods are (inevitably) purchased by others) - do not appear to be relevant to corporate governance, much less to limited liability of shareholders.

98 Schwarcz, supra note 3, at 625; see also Klára Bakk-Simon et al., European Central Bank Occasional Paper No. 133, Shadow Banking in the Euro Area: An Overview 3 (Apr. 2012) (observing that disintermediation is "one of the main sources of financial stability concerns").

99 Steven L. Schwarcz, Systemic Risk, 97 GEo. L.J. 193, 207, 235 (2008) (attempting to estimate the costs of a systemic failure of the financial system, which could go beyond direct economic costs and include indirect "social costs in the form of widespread poverty and unemployment”); cf. Iman Anabtawi \& Steven L. Schwarcz, Regulating Systemic Risk: Towards an Analytical Framework, 86 Notre Dame L. Rev. 1349, 1376 n.109 (2011) (arguing that because financial market participants are able to externalize significant social costs associated with their risk-taking, it is in their interest to take on excessive risks and oppose regulatory efforts to curtail, or increase the costs of, their ability to do so).

100 Economists often recognize, for example, that a market failure has occurred if the production of goods or services results in externalities. See, e.g., Francis M. Bator, The Anatomy of Market Failure, 72 Q.J. Econ. 351, 351 (1958) (defining market failure as "the failure of a more or less idealized system of price-market institutions to sustain 'desirable' 
When discussing the causes of market failures, I have proposed that we substitute for "externalities" the term "responsibility failure"-referring to responsibility for a firm's ability to externalize a significant portion of the costs of taking a risky action. ${ }^{101}$ This Article will use this more precise terminology.

This Article therefore next analyzes limited liability in the shadow banking system from the standpoint of three market failures: agency failure, information failure, and responsibility failure. To further clarify the terminology, references below to "limited liability" shall mean limited liability of equity investors; references below to "equity investors" shall mean shareholders and other persons, whether or not they own shares of stock, who share in the firm's profits; ${ }^{102}$ and references below to "investors" shall mean equity investors.

\section{B. Applying the Framework to Shadow Banking}

\section{Limited Liability and Agency Failure}

Agency failure refers to conflicts of interest between principals and their agents-in our case, between a firm and its investors on the one hand and the firm's managers on the other hand. ${ }^{103}$ Examples would include conflicts between investors of a firm and the firm's officers and directors. This market

activities or to estop 'undesirable' activities"). The cause of the market failure is not externalities per se, however; rather, it is the problem with the production of goods and services that resulted in the externalities. The externalities merely signal that a market failure has occurred. Cf. Mark Sunshine, How Did Economists Blow It (Part 2)? - They Missed the Negative Externalities of America's Limited Liability Society, Sunshine Rep. (Sept. 8, 2009), http://www .thesunshinereport.net/marksunshine/?p=402 (arguing that although economic "theories about efficient markets and logical behavior are pretty good, the fundamental application of these theories stinks").

101 Schwarcz, supra note 1, at 1799-1800. Referring to externalities as a type of market failure is also misleading because externalities cannot be considered a truly distinct type of market failure; all types of market failures can result in externalities. Richard O. Zerbe Jr. \& Howard E. McCurdy, The Failure of Market Failure, 18 J. Pol'y Analysis \& Mgmt. 558, 561 (1999); $c f$. Andreas A. Papandreou, Externality and Institutions 167-69 (1994) ("[I]f externality is simply another word for market failure, or institutional failure . . the notion of externality becomes redundant."). To avoid this circularity, some economists have even questioned whether "externalities" should denote a separate market-failure category. See, e.g., Papandreou, supra, at 99-100 (arguing that the "non-existence of markets" is the actual market failure referred to as "externalities" and that it is "not useful to treat externalities as a subset of market failure, nor for that matter as a cause of market failure"); Zerbe \& McCurdy, supra, at 562 (arguing that externalities should not be defined as market failures); $c f$. id. at 564 (arguing that "a close examination of the market failure concept gives rise to all sorts of definitional problems" related to externalities).

102 This might include, for example, a manager who has a bonus-compensation scheme based on the firm's profits.

103 Because it is not a principal-agent conflict, agency failure does not include the conflict in which investor-managers have strong incentives to take risks that could generate outsized profits, even if that greatly increases systemic risk. 
failure does not appear to be directly relevant to analyzing the limited liability of investors. ${ }^{104}$

\section{Limited Liability and Information Failure}

Information failure refers to asymmetric information, or even mutual misinformation, between parties. An example of the former would be the insufficiency of disclosure to completely inform investors of the merits and risks of a highly complex securities investment. ${ }^{105}$ Information failure can arise from various causes, including the potential for transaction costs relating to information acquisition to diminish the incentive to acquire such information. ${ }^{106}$

This market failure is directly relevant to limited liability. If investors stand only to lose their equity investments in a firm, they will have limited incentives to incur costs monitoring the firm. I next argue, however, that monitoring incentives will be even more limited for investors of shadow banking firms. Among other reasons, it is because those investors may not bear all of the adverse consequences of such limited monitoring. ${ }^{107}$ Increasing investor liability can help to increase those monitoring incentives.

That does not fully address, however, the design of the monitoring incentives. Ideally, increasing investor liability should encourage not only monitoring of the firm, qua firm; it also should encourage monitoring of the firm's potential to trigger systemic risk, thereby externalizing risk. I next address that concern.

\section{Limited Liability and Responsibility Failure}

In the shadow banking system, limited liability is an important source of responsibility failure that can lead to externalities-and, even more signifi-

104 See generally Schwarcz, supra note 8 . This market failure may be indirectly relevant to limited liability. For example, the greater the investor liability, the greater the incentive of investors to align managers to their interests.

105 See Lee C. Buchheit, Did We Make Things Too Complicated?, 27 InT'L Fin. L. Rev. 24, 26 (2008) (noting that "[c] omplexity can obscure the risks of [financial] transaction[s]"); Steven L. Schwarcz, Disclosure's Failure in the Subprime Mortgage Crisis, 2008 Utah L. Rev. 1109, 1110 [hereinafter Schwarcz, Disclosure's Failure] (noting that the prospectus in a securities offering is often hundreds of pages long); Steven L. Schwarcz, Regulating Complexity in Financial Markets, 87 WASH. U. L. REv. 211, 214-15 (2009) [hereinafter Schwarcz, Regulating Complexity]; cf. John D. Finnerty \& Kishlaya Pathak, A Review of Recent Derivatives Litigation, 16 Fordham J. Corp. \& Fin. L. 73, 74 (2011) (observing that court records reveal investors' misunderstandings about the nature of derivative financial instruments).

106 See Sanford J. Grossman \& Joseph E. Stiglitz, On the Impossibility of Informationally Efficient Markets, 70 Am. Econ. Rev. 393, 395-405 (1980); Schwarcz, Disclosure's Failure, supra note 105, at 1113-15; cf. Schwarcz, supra note 64, at 504 (observing that when numerous investors have rights in a class of securities, investors individually might lack a sufficient amount at risk to motivate monitoring).

107 See infra notes 121-31 and accompanying text (explaining why investors of shadow banking firms will not bear all of the adverse consequences of a systemic collapse). 
cantly, to systemic externalities. ${ }^{108}$ If a shadow banking firm cannot pay all of the externalized harm for which it becomes liable, the firm's investors will not (qua investors) be financially responsible beyond the capital they have invested. To that extent, limited liability creates moral hazard. ${ }^{109}$

Admittedly, limited liability creates moral hazard even outside the shadow banking system. It is widely understood, for example, that "most of a corporate structure's externalities result from the limited-liability rule of corporation law." 110 Moral hazard in shadow banking, however, is more likely to have systemic consequences. There are two reasons why: decentralization makes managers of limited liability shadow banking firms more likely to take risks than managers of other limited liability firms, thereby making shadow banking firms more likely to fail; and disintermediation makes the consequences of a shadow banking firm's failure more likely to be systemic than the consequences of an ordinary firm's failure.

First consider why decentralization makes managers of limited liability shadow banking firms more likely to take risks than managers of other limited liability firms. The relatively small firms, such as hedge funds, that operate in the shadow banking system are often managed directly by their primary investors. ${ }^{111}$ Because such investor-managers typically are entitled to a significant share of their firm's profits, ${ }^{112}$ they have strong incentives to take risks that could generate large profits. ${ }^{113}$ Some risks might even poten-

108 Cf. Edouard Challe et al., Equilibrium Risk Shifting and Interest Rate in an Opaque Financial System, Ecole Polytechnique, Centre National de la Recherche Scientifique, Sept. 2012, at 6, available at http://hal.archives-ouvertes.fr/docs/00/72/89/28/PDF/ 2012-19.pdf (noting that systemic risk arises partially because limited liability increases intermediaries' risk tolerance).

109 See supra notes 63-64 and accompanying text (discussing limited liability and moral hazard).

110 Steven L. Schwarcz, Collapsing Corporate Structures: Resolving the Tension Between Form and Substance, 60 Bus. Law. 109, 144 (2004).

111 See Stacy Preston Collins, Valuation of Hedge Fund Businesses, 21 J. Am. Acad. Matrim. L. 389, 397 (2008) (noting that hedge fund managers often have to commit a significant amount of their own capital); Richard M. Hynes, Securitization, Agency Costs, and the Subprime Crisis, 4 VA. L. \& Bus. Rev. 231, 236 (2009) (noting that managers of small banks and thrifts can own a large share of their firms' equity).

112 See, e.g., Mercer Bullard, Regulating Hedge Fund Managers: The Investment Company Act as a Regulatory Screen, 13 Stan. J.L. Bus. \& Fin. 286, 288 (2008) (noting that hedge fund managers often receive the right to twenty percent of the funds' performance that exceeds a minimum "performance floor"); Economic Analysis of the Split of Profits Between Hedge Fund Investors and Hedge Fund Management by Merrill Lynch $\mathcal{E}^{2}$ Co. Inc., OrG. FOR Econ. Co-OPERATION AND DEv. 6, http://www.oecd.org/tax/taxadministration/18474849.pdf (last visited Oct. 10, 2014) (noting that, during the period 1998 to 2002, hedge fund managers generally received around twenty percent of their funds' profits).

113 Consider, for example, William Ackman's recent failed bet on J.C. Penney. Ackman is founder and CEO of the hedge fund Pershing Square Capital Management, LP. See William Ackman, Forbes, http://www.forbes.com/profile/william-ackman/ (last visited Oct. 10, 2014). In October 2010, Ackman disclosed that Pershing Square had acquired a 16.5 percent stake in the then struggling J.C. Penney Co. See Maxwell Murphy, How Bill Ackman Stalked J.C. Penney, Wall St. J. (Oct. 8, 2010, 3:50 PM), http://blogs.wsj.com/ 
tially generate such outsized profits that investor-managers would gain lifetime financial security. ${ }^{114}$ Yet if a risky action exposes their firm to significant liability for externalized harm, limited liability protects those investor-managers from losing more than their invested capital.

This is radically unlike the management incentives in non-shadow banking firms. In those firms (such as ordinary business corporations and even traditional banks), senior managers tend to share only indirectly in profits, such as through stock options. Most profits ordinarily are paid to non-manager investors. ${ }^{115}$ Furthermore, managers are often invested in maintaining their jobs. ${ }^{116}$ They are therefore much less motivated to take actions that risk the firm, such as exposing the firm to significant liability for externalized harm. ${ }^{117}$

Managers of limited liability shadow banking firms are thus more likely to take risks than managers of other limited liability firms, thereby making shadow banking firms more likely to fail. ${ }^{118}$ That likelihood of failure is fur-

deals/2010/10/08/how-bill-ackman-stalked-jc-penney/. At the time, Ackman was betting that he could transform J.C. Penney, an extremely risky venture that was met with significant skepticism. Id. The total cost of Ackman's bet on J.C. Penney would eventually total $\$ 1$ billion and include him taking a seat on the J.C. Penney board. Svea Herbst-Bayliss, Bad JC Penney Bet Calls Ackman's Retail Acumen into Question, Reuters (Aug. 13, 2013), http:// www.reuters.com/assets/print?aid=USBRE97C0ZI20130813. In August 2013, Ackman accepted that his bet was a mistake. Id. He resigned from the J.C. Penney board and sold his investment in J.C. Penney generating a loss of more than $\$ 600$ million. James Sterngold, Ackman's Pershing Square Takes \$1.2 Billion Hit, Wall ST. J., (Oct 4, 2013, 2:02 PM), http://online.wsj.com/news/articles/SB1000142405270230372260457911366161649 1516. This risky bet on J.C. Penney combined with another failed risky bet on Herbalife Ltd. has led to a decline in the assets under Pershing Square's management of $\$ 1.2$ billion, which is approximately ten percent. $I d$.

114 Steven L. Schwarcz, Understanding the Subprime Financial Crisis, 60 S.C. L. Rev. 549, 562-63 (2009) (discussing how "super-large compensation" can skew incentives).

115 See, e.g., Robert Boldin \& Keith Leggett, Bank Dividend Policy as a Signal of Bank Quality, 4 Fin. Services Rev. 1, 1 (1995) (noting that industry-wide bank payout ratios on stock have reached eighty percent); Nikola Spatafora, Global Financial Stability Report: Responding to the Financial Crisis and Measuring Systemic Risks, in The Global Financial Crisis 2009, at 319, 379 (2009) (describing how Basel III might reduce long-term bank stockdividend payout ratios from sixty percent, pre-crash, to forty percent).

116 Cf. Claire A. Hill, Is Secured Debt Efficient?, 80 Tex. L. Rev. 1117, 1156 (2002) (describing how managers who do not own a substantial portion of the firm may be better agents for lenders' interests because of "managers' desire to keep their jobs, which depends on the firm's continuing financial viability").

117 Cf. Henry T.C. Hu, Risk, Time, and Fiduciary Principles in Corporate Investment, 38 UCLA L. REv. 277, 320 (1990) ("[In a traditional firm] [t] he manager cannot take as cavalier an attitude toward the diversifiable risks of his corporation as the stockholder can. If a corporation does badly because a new investment project fails, a manager must rely primarily on other projects undertaken by the same corporation to balance against it. His salary and prospects and his value to a potential new employer would be hurt by poor firm performance.").

118 Shadow banking firms are also more likely to fail than traditional banks because they are not subject to the type of solvency/prudential regulation imposed on traditional banks, see infra note 124, and also because shadow banking firms are not limited in their 
ther increased by the fact that shadow banking financial intermediation, like traditional bank financial intermediation, often involves the short-term funding of long-term projects. ${ }^{119}$ This creates a liquidity risk that the short-term debt cannot be rolled over. A failure to roll over (i.e., refinance) short-term debt could result in the firm's default. ${ }^{120}$

The consequences of a shadow banking firm's failure are also more likely to be systemic than the consequences of an ordinary firm's failure. Like traditional banks, shadow banking firms engage in financial intermediation on which the real economy is dependent. Because all financial intermediaries-including shadow banking firms and traditional bankstend to be highly interconnected, the failure of a shadow banking firm could trigger the failures of other financial intermediaries. ${ }^{121}$ Such a chain of failures would be the epitome of a systemic event, especially if it materially reduces the availability of financial intermediation. ${ }^{122}$

Additionally, the aforesaid short-term funding of long-term projects not only increases the likelihood of a shadow banking firm's failure ${ }^{123}$ but can increase the systemic consequences of that failure. Among other reasons, an event that prevents one shadow banking firm from refinancing can also prevent-or can be correlated to other events that also prevent-other shadow banking firms from refinancing. Because shadow banking does not (at least currently) require the type of solvency/prudential regulation imposed on traditional banks, ${ }^{124}$ such a correlated failure would be highly systemically

activities to financial intermediation so they can also take other types of business risks. See Andrew Crockett \& Benjamin H. Cohen, Financial Markets and Systemic Risk in an Era of Innovation, 4 INT'L FIN. 127, 137-38 (2001) (discussing that the expanded range of activity by financial institutions has increased "the exposure of institutions to [market] shocks" and also observing that the wider range of markets in which financial institutions are engaged has increased the "number of potential channels of propagation of shocks").

119 SIVs, for example, issue short-term commercial paper to fund long-term projects. See Schwarcz, supra note 1, at 1805. Money-market mutual funds also provide short-term loans to fund long-term projects. Id. Admittedly, the traditional business of banking also uses short-term borrowing from depositors to finance long-term loans to bank customers. $I d$. at 1806 . However, the potential systemic externalities are offset by prudential regulation and deposit insurance. See infra note 124.

120 See Schwarcz, supra note 1, at 1806.

121 See Anabtawi \& Schwarcz, supra note 99, at 1355 ("The financial system is comprised of institutions that are highly interrelated. In this sense, it is a 'network.'" (citing Markus K. Brunnermeier, Deciphering the Liquidity and Credit Crunch 2007-2008, 23 J. Econ. PersP. 77, 96 (2009))); see also id. at 1356-61 (explaining how inter-institution correlation, or interconnectedness, helps to explain why certain failures become systemic and others, like Enron's failure, do not).

122 See Schwarcz, supra note 99, at 204.

123 See supra notes 119-120 and accompanying text.

124 In bank-intermediated finance, systemic externalities, specifically bank runs, are mitigated by prudential regulation and deposit insurance. See Schwarcz, supra note 1, at 1810-11. In contrast, prudential regulation does not or cannot be applied to many shadow banking firms. Id. at 1811-15. Meanwhile, disintermediation by spurring the short-term funding of long-term projects can mimic the effects of a bank run. Id. at 1807-08. Section 113 of the Dodd-Frank Wall Street Reform and Consumer Protection Act empowers the 
risky. Economists have identified the failure of shadow banking firms to roll over short-term debt as a contributing factor to the global financial crisis. ${ }^{125}$

In summary, although the limited liability of firms can always cause externalities, the limited liability of shadow banking firms is much more likely than the limited liability of non-shadow banking firms to cause systemic externalities. This is certainly a quantitative distinction: systemic externalities can cause much more harm than non-systemic externalities. ${ }^{126}$ I next argue that this is also a qualitative distinction.

An important function of law, and in particular tort law, is to operate as a mechanism for internalizing a firm's externalities. By empowering injured third parties to sue a firm for harm, tort law helps to internalize a firm's externalities because the firm will either pay the cost of the externalities ex post through a judgment or will not engage in the activity ex ante to avoid the potential costs of an adverse judgment. Still, limited liability has practical consequences for traditional banking firms: third parties injured by even non-systemic harm are not always able to recover damages that perfectly internalize the harm because the firm causing the harm may have insufficient capital to pay the damages. ${ }^{127}$

The consequences of limited liability for shadow banking firms, however, are qualitatively different: third parties injured by systemic harm will have virtually no chance to recover damages that internalize the harm. Although this difference arises partly because shadow banking firms are unlikely to have sufficient capital to pay for the massive and widespread harm caused by a systemic collapse, ${ }^{128}$ the conceptual reason for the difference is legal. As explained below, existing law does not-and adaptations to traditional law are unlikely to-effectively internalize that harm.

Financial Stability Oversight Council (FSOC) to designate nonbank financial institutions as systemically important financial institutions (SIFIs) and therefore subject them to consolidated supervision by the Federal Reserve and enhanced prudential standards. Notably, as of this writing, only three firms have been designated as SIFIs by the FSOC. Designations, Fin. Stability Oversight Council, http://www.treasury.gov/initiatives/fsoc/designations/Pages/default.aspx (last updated Dec. 17, 2013, 3:47 PM) (listing designated SIFIs as only American International Group, Inc., General Electric Capital Corporation, Inc., and Prudential Financial, Inc.).

125 See Schwarcz, supra note 1, at 1807-08 (discussing the findings of economists Gary Gorton and Andrew Metrick, Federal Reserve Board economists, and the European Central Bank).

126 See supra note 99 and accompanying text.

127 Cf. supra notes 62-64 and accompanying text (discussing scholarly arguments that limited liability generally encourages firms to engage in riskier, and therefore more tortprone, projects than is socially optimal). Third parties injured by non-systemic harm, specifically tort victims, might not always be able to recover damages. Cf. Hansmann \& Kraakman, supra note 31, at 1881 ("Already, strong empirical evidence indicates that increasing exposure to tort liability has led to the widespread reorganization of business firms to exploit limited liability to evade damage claims.").

128 Cf. Schwarcz, supra note 99, at 206 (discussing the extent and magnitude of that harm). 
As mentioned, tort law operates as a mechanism for internalizing a firm's externalities. To win their lawsuits, injured third parties normally must show their harm to be a causal ${ }^{129}$ and foreseeable ${ }^{130}$ consequence of the firm's actions. Third parties injured by systemic harm caused by the firm's actions would unlikely be able to show that, however. Systemic harm can affect a wide range of third parties in unpredictable ways, such as an individual who is forced to close her family-owned restaurant during a systemically caused recession. Nor is it likely that changing the causation-and-foreseeability standard to enable third parties to win those lawsuits would be an efficient solution. ${ }^{131}$ At the very least, courts would face a line-drawing problem and would be forced to make complicated decisions as to what systemic externalities should (or should not) be considered compensable.

The analysis has shown that limited liability investors of shadow banking firms lack sufficient monitoring incentives to avoid engaging in systemically risky actions, and that adaptations to traditional legal remedies are unlikely to adequately internalize systemic externalities. I next examine whether redesigning limited liability could be a more efficient solution to this problem. ${ }^{132}$

\section{Redesigning Limited Liability}

Because it increases responsibility failure in the shadow banking system, limited liability should be redesigned if the benefits of the redesign outweigh the costs. This Part examines how that might be done.

129 Under the "but-for" test of causation, "causation exists only when the result would not have occurred without the party's conduct." Black's Law Dictionary, supra note 2, at 228.

130 Foreseeability is an element of proximate cause in tort law, defined as "[t]he quality of being reasonably anticipatable." Id. at 250, 721. Civil damages are normally imposed only for foreseeable harms. Steven L. Schwarcz \& Lucy Chang, The Custom-to-Failure Cycle, 62 Duke L.J. 767, 789 (2012).

131 In theory, civil damages can be imposed under existing law for all harms, regardless of foreseeability, pursuant to the allocation-of-resources justification of enterprise liability. See Guido Calabresi, Some Thoughts on Risk Distribution and the Law of Torts, 70 Yale L.J. 499, 529 (1961). The rationale for enterprise liability is that prices should reflect the "actual costs" of goods so as to allow purchasers to make informed decisions. Id. at 502. Therefore, "the cost of injuries should be borne by the activities which caused them," regardless of fault, because injuries represent a "real cost" of those activities. Id. at 505. Foreseeability is irrelevant under enterprise liability because unforeseeable harms are "just as truly costs" of doing business as foreseeable harms. Id. at 529.

132 Other possible non-traditional legal solutions, such as regulation directed at ensuring shadow banking firm solvency, are beyond the scope of this article. Cf. PosNer, supra note 9, at 413-14 (stating that "it is arguable that the government should take a more active role in assuring the solvency of corporations" to mitigate externalities caused by corporate limited liability, and observing that "the regime in banking ... and in European corporate law" uses "continuous regulatory scrutiny of the corporation by an administrative agency"). 


\section{A. Setting Goals for Redesigning Limited Liability}

Any redesign of limited liability should at least take into account its traditional justifications. The goal of the "efficiency" justification is to create incentives for widespread investor participation in equity ownership. ${ }^{133}$ Investors have risk aversion; ${ }^{134}$ the more risk they are exposed to, the less incentive they will have to invest. Even fully rational investors will refuse to invest if their risk is unlimited, because the expected value of their losses might well exceed the expected value of their gains. ${ }^{135}$

Therefore, any redesign of limited liability should attempt not only to minimize investor risk aversion but also to make investors comfortable that the expected value of their potential gains should exceed (by a sufficient margin to encourage investment) the expected value of their potential losses. ${ }^{136}$ The most effective way to accomplish that would be to set some type of cap or limit—such as double liability, which a recent study suggests is a "superior alignment of liabilities and incentives"137_on the potential liability.

Another traditional justification for limited liability is that it reduces monitoring costs because an investor need not overly worry about monitoring the firm's risky actions, for which the investor could ultimately become liable. ${ }^{138}$ In the shadow banking system, this justification should be given less weight because the potential for shadow banking firms to trigger systemic risk may well justify, if not necessitate, increased monitoring.

A related monitoring-cost justification for limited liability is that an investor need not worry about monitoring the wealth of other investors, whose liability the investor could ultimately bear under a joint-and-several liability regime. ${ }^{139}$ This risk-including the complications it entails due to the free transferability of equity shares-could be avoided by a redesign, such as double liability, in which any given investor's liability would be independent of the liability of other investors.

Yet another traditional justification for limited liability is that by promoting the free transfer of shares, it serves to create incentives for managers to act efficiently: investors can transfer their shares if managers perform poorly,

\section{See supra notes $85-87$ and accompanying text.}

134 Persons seeking gain tend to be risk averse. See Steven L. Schwarcz, The Inherent Irrationality of Judgment Proofing, 52 Stan. L. Rev. 1, 27 (1999).

135 But cf. Conti-Brown, supra note 77, at 414, 446 (arguing that the successful operation of investment banks as partnerships until late in the twentieth century suggests that limited liability may not be needed).

136 A related justification for limited liability was that as corporations increase in size, there are more associated risks, and the risks are consequently of much larger scale, which can serve to discourage investment by all but the wealthiest of investors. Blumberg, supra note 16, at 612-13. Shadow banking firms, however, tend to be relatively smaller.

137 See White, supra note 7, at 4.

138 See supra note 89 and accompanying text.

139 See supra note 90 and accompanying text. 
and the new investors can install new managers. ${ }^{140}$ This justification does not appear to be compelling. ${ }^{141}$ Even existing investors could choose to vote out existing managers.

The final traditional justification for limited liability turns on fairness: that imposing additional liability on investors who did not contribute to management decisions created a perception of unfairness. ${ }^{142}$ If, however, such liability is imposed only on investor-managers, which is this Article's shadow banking focus-and perhaps only on investor-managers with the power to "control" the firm-then it should be more consistent with the fairness justification. ${ }^{143}$ Moreover, imposing such liability on only those investors would be efficient insofar as it ties the increase in liability to control over risk-taking decisions. ${ }^{144}$

In sum, any redesign of limited liability in the shadow banking system should have at least the following goals: (i) it should increase such liability in a way that increases investor incentives to monitor (and guard against) the

140 See supra notes 91-92 and accompanying text.

141 This justification may make even less sense for shadow banking firms, like hedge funds, that are closely held. Some argue that limited liability is not efficient for small, closely held corporations. Halpern et al., supra note 90, at 148. Their rationale includes the argument that this limited liability then introduces more aggregate costs than in large, publicly traded corporations and also incentivizes shifting risk to parties less capable of bearing it, such as involuntary and trade creditors. See Judith Freedman, Limited Liability: Large Company Theory and Small Firms, 63 Mod. L. Rev. 317, 332-35 (2000).

142 See supra notes 56-57 and accompanying text (discussing this liability in the context of double liability of bank shareholders). It may well be appropriate to consider fairness as a normative goal. See, e.g., Louis Kaplow \& Steven Shavell, Fairness Versus Welfare, 114 Harv. L. REv. 961, 1015 (2001) (arguing that it is appropriate to consider distributional fairness in making a policy decision).

143 Investor-manager liability may also have indirect benefits. For example, limited liability might undermine - and thus increasing liability might support-the business judgment rule and the policies behind the rule, such as keeping courts from judging business decisions through hindsight-biased lenses, and allowing managers to take the risks necessary for maximizing investor value. See, e.g., In re Citigroup Inc. S'holder Derivative Litig., 964 A.2d 106, 124 (Del. Ch. 2009) (stating that doctrines such as the business judgment rule "properly focus on the decision-making process rather than on the substantive evaluation of the merits of the decision" to counteract the hindsight bias that some courts exhibit); Wulf A. Kaal \& Richard W. Painter, Initial Reflections on an Evolving Standard: Constraints on Risk Taking by Directors and Officers in Germany and the United States, 40 Seton Hall L. Rev. 1433, 1440-41, 1449 n.56 (2010) (stating that "managers often must take reasonable risks" in the ordinary course of business and arguing that hindsight bias can have a significant influence on whether risks taken are viewed as reasonable or excessive); $c f$. John Armour \& Jeffrey N. Gordon, Systemic Harms and Shareholder Value, 6 J. Legal Analysis 35 (2014), available at http://papers.ssrn.com/sol3/papers.cfm?abstract_id=2307959 (arguing that the business judgment rule protection, which makes sense for officers and directors of a non-financial firm, leads to excessive risk-taking in a systemically important financial firm, and proposing officer and director liability rules to counter that risktaking).

144 Cf. Erik Gerding, United States of America, in Directors' Personal Liability for CorPORATE Fault 301, 324-25 (Helen Anderson ed., 2008) (discussing the economics of imposing liability on officers and directors). 
firm's potential to trigger systemic risk; (ii) it should minimize investor risk aversion and encourage investment by setting a cap on liability sufficient to make investors comfortable that the expected value of their potential gains should exceed, by a sufficient margin, the expected value of their potential losses; (iii) it should discourage cross-investor monitoring by ensuring that any given investor's liability is independent of the liability of other investors; and (iv) to ensure fairness and maintain efficiency, it should increase liability only for investor-managers (because it is that dual nature that creates the real risk).

Because certain of these goals are in tension, no possible redesign of limited liability could ever perfectly achieve all of these aims. For example, the greater the investor liability, the more investment would be discouraged. ${ }^{145}$ Any redesign would also have to confront the collective action problem of cross-border capital flight. I have already discussed how increasing investor liability might trigger capital flight between states. ${ }^{146}$ Domestically, increasing investor-manager liability under federal law, as opposed to state law, could solve that problem. ${ }^{147}$ The collective action problem could also arise internationally, however. If one or more nations increases investor liability, investors may decide to move their money to firms in other nations, creating an international collective action problem. Cross-border cooperation would be needed to help mitigate that problem. ${ }^{148}$

Finally, in furthering the first of these goals-increasing investor incentives to monitor and guard against systemic risk-this Article does not claim

$145 C$ C. White, supra note 7, at 8 (observing a "potential trade-off" insofar as modifying limited liability might "create[] an incentive that induce[s] [bank] shareholders to act more cautiously, reining in managers' efforts to expand loans that contributed to the growth of the economy"). Another potential concern is that increasing investor liability could make equity investments even more relatively expensive than debt, thereby increasing leverage. Although that is a theoretical concern, so many other considerations go into the determination of a firm's capital structure that I do not believe it is likely to become a practical concern (and if it ever becomes a practical concern, that concern could be addressed through the issuance of non-voting equity).

146 See supra note 55 and accompanying text.

147 Federal law constitutionally allows piercing of the corporate veil to impose controlperson liability in furtherance of federal statutory policies. Cf. Pension Benefit Guar. Corp. v. Ouimet Corp., 630 F.2d 4, 12 (1st Cir. 1980) (holding that the Employee Retirement Income Security Act's (ERISA) imposition of plan-termination liability jointly and severally on the plan sponsor and all members of its control group is not an unconstitutional denial of due process).

148 The Basel Capital Accords exemplify global rules intended to help avoid prejudicing the competitiveness of firms-in this case, banks-in any given nation or region. See, e.g., Arie C. Eernisse, Banking on Cooperation: The Role of the G-20 in Improving the International Financial Architecture, 22 DukE J. Comp. \& INT'L L. 239, 254-56 (2012) (discussing the Basel III capital and liquidity framework and its emphasis on consistent global standards); Clyde Stoltenberg et al., The Past Decade of Regulatory Change in the U.S. and EU Capital Market Regimes: An Evolution from National Interests Toward International Harmonization with Emerging G-20 Leadership, 29 Berkeley J. Int'L L. 577, 615-44 (2011) (examining U.S. and E.U. efforts to adopt harmonized financial standards). 
that systemic risk could be eliminated. ${ }^{149}$ Nonetheless, that goal is important because systemic externalities are the externalities most likely to cause widespread and serious harm. ${ }^{150}$

\section{B. Testing Redesign Proposals Against the Goals}

This Article does not purport to test all possible proposals to redesign limited liability against the foregoing goals. Consider in the context of the shadow banking system, however, the generalized proposals referenced earlier. ${ }^{151}$ Professors Hill and Painter propose using compensation as the test, imposing personal liability on investors that earn over a threshold number (such as $\$ 3$ million annually). ${ }^{152}$ A purely compensation-based test has the drawback, however, that it does not target only investor-managers. Additionally, a compensation-based test might be able to be manipulated by creatively structuring compensation in ways that avoid the test. ${ }^{153}$ Professors Hansmann and Kraakman propose the use of pro rata, unlimited investor liability, under which investors would be liable in proportion to their investment. ${ }^{154}$ Their proposal has two drawbacks: it may discourage investment because it does not set a cap on liability, and it does not target only investormanagers. Professor Mendelson proposes the use of a control-based liability regime under which only investors with the "capacity to control" would be liable. ${ }^{155}$ This proposal should be superior to pro rata, unlimited investor liability because it better aligns the costs of risky activities with control. In a pro rata regime a controlling investor-manager's liability is limited by his share of corporate equity and not his actual influence on risky activities. ${ }^{156}$

149 For analysis of the limits of law to control systemic risk, see Steven L. Schwarcz, Controlling Financial Chaos: The Power and Limits of Law, 2012 WIs. L. Rev. 815, 829-33 (discussing requiring banks and systemically important nonbanks to pay for a systemic risk protection fund in order to help to internalize the most harmful externalities of the shadow banking system while stabilizing systemically important firms and markets); Viral V. Acharya et al., A Tax on Systemic Risk, N.Y.U. Stern, The Volatility Inst. 2-4 (Feb. 3, 2010), http://vlab.stern.nyu.edu/public/static/SR-tax-nber.pdf (arguing that each institution should be required to pay a "tax" that is calculated according to the extent to which that institution is likely to contribute to systemic risk). Indeed, the law generally does not require that all externalities be internalized. See, e.g., Michael J. Trebilcock, The Limits of Freedom of Contract 20 (1993) (asking what types of externalities the law should require to be internalized).

150 Schwarcz, supra note 99, at 206.

151 Those proposals are generalized insofar as they are not designed specifically for the shadow banking system. They nonetheless are worth testing because they reflect the serious thoughts of respected scholars on limited liability generally. See, e.g., Hill \& Painter, supra note 80.

152 See id. at 1188.

153 It also is unclear how Hill and Painter's proposal addresses risk aversion; they do not specify whether investor liability should be subject to any cap. See id.

154 See supra note 65 and accompanying text.

155 See supra note 66 and accompanying text.

156 By the same logic that investors with the "capacity to control" can use their unique position to induce the corporation to engage in excessively risky activities, these investors 
However, Mendelson's proposal may discourage investment because it does not set a cap on liability.

Furthermore, a drawback to all of these referenced proposals is that they fail to effectively address systemic risk. ${ }^{157}$ Any redesign of limited liability must resolve the dilemma that investor-managers would have relatively little incentive to monitor and guard against their firm's potential to trigger systemic risk if, as argued, tort law bars third parties injured by systemic harm from recovering damages. ${ }^{158}$

A possible solution to this dilemma would be to couple any increase in limited liability with a privatized systemic risk fund-which would be used to mitigate systemic harm ${ }^{159}$ _into which systemically risky shadow banking firms would be required to contribute. ${ }^{160}$ Privatizing the funding would help to reduce a shadow banking firm's incentive to create systemic externalities by engaging in financially risky activities; ${ }^{161}$ indeed, the likelihood that firms will have to make additional contributions to the fund to replenish bailout monies should motivate them to monitor each other and help control each other's risky behavior. ${ }^{162}$ Making investor-managers personally liable, subject to a cap, for shortfalls in their firm's fund contributions would likewise motivate them to monitor and help control their firm's systemically risky behavior. ${ }^{163}$

can also use their unique position to limit firm risk. See Mendelson, supra note 16, at $1280-85$.

157 Indeed, it is the inherently systemically risky nature of shadow banking that limits this Article's recommendations to the shadow banking sector. I am not suggesting, for example, that limited liability be changed for operating companies that do not engage in financial intermediation, even if such companies are run by dominant shareholders. The consequences of such a company's failure are not likely to be systemic, and-all things being equal-the tort system is more likely to enable injured third parties to recover from the company, thereby helping to internalize the cost of the failure.

158 See supra notes 128-30 and accompanying text. Because there is always some risk of losing a lawsuit, investor-managers should have some incentive, albeit limited, to monitor and guard against their firm's potential to trigger systemic risk.

159 See, e.g., Schwarcz, supra note 149, at 829-30.

$160 I d$. (discussing, among other things, how a privatized systemic risk fund could assess which firms are systemically risky and how much each such systemically risky firm should be required to contribute).

$161 I d$. at 830.

$162 I d$. at 830-31. Because their own funds would be at risk, for example, fund contributors would have incentives to inform regulators when other firms take unwise risks. Jeffrey N. Gordon \& Christopher Muller, Confronting Financial Crisis: Dodd-Frank's Dangers and the Case for a Systemic Emergency Insurance Fund, 28 YaLE J. ON REG. 151, 155-56 (2011) (calling for a systemic emergency insurance fund that is funded by the financial industry). If the required contributions to the fund were risk-adjusted, fund contributors would also have incentives to report firms that are underpaying. Schwarcz, supra note 149, at 831.

163 Any redesign should attempt to take into account, however, the fairness of making investor-managers of a firm personally liable for that firm's additional fund contributions necessitated by systemic harm caused by other firms. 


\section{Conclusion}

We tend not to focus on liability limitation at the firm level, simply accepting it as a fact of life. Limited liability is not always optimal, however, for firms that make up the shadow banking system. It motivates investormanagers of those firms to take risks that could generate outsized personal profits, even if that greatly increases systemic risk.

The law does not effectively mitigate these systemic externalities. Tort law, for example, traditionally helps to mitigate non-systemic externalities resulting from limited liability by empowering injured third parties to sue for harm that is a causal and foreseeable consequence of the tortfeasor's actions. Systemic harm, however, affects a wide range of third parties in unpredictable ways; it is neither directly causal nor clearly foreseeable.

To mitigate systemic externalities, limited liability should be redesigned, as explained in this Article, for investor-managers of shadow banking firms. Any such redesign must balance the need to increase liability sufficiently to reduce systemic risk with not discouraging investment. The redesign should also minimize costs by discouraging the need to engage in cross-investor monitoring. These competing goals may well be achievable by restricting the increased liability to a capped multiple of the original investment, such as double liability.

Regardless of how limited liability is redesigned, it faces the dilemma that investor-managers would have relatively little incentive to monitor and guard against their firm's potential to trigger systemic risk if, as indicated, tort law bars injured parties from recovering damages. A possible solution to this dilemma would be to couple the redesigned limited liability with a privatized systemic risk fund-which would be used to mitigate systemic harminto which systemically risky shadow banking firms would be required to contribute. If an investor-manager's firm had insufficient capital to make these contributions, the investor-managers would become personally liable for at least a portion of the insufficiency, thereby motivating them to monitor and help control their firm's systemically risky behavior.

An ultimate question for any redesign of limited liability is empirical: will its benefits exceed its costs? The answer to that question will depend on the actual mechanics of the redesign, and their real-world impact on risk-taking and investment. Annex I below sets forth practical considerations that are likely to be relevant to any such cost-benefit determination. 


\section{ANNEX I}

\section{Guidance on Redesigning Limited Liability}

This Annex provides practical guidance on redesigning limited liability, including guidance for assessing costs and benefits. Such guidance is qualified by, and intended to be interpreted by reference to, the more complete analysis in the Article itself.

1. Limited liability should be increased only for investor-managers of firms that operate in the shadow banking system. Because the parameters of shadow banking are not yet well defined, ${ }^{164}$ the redesign should take into account how to delimit those firms. Because the primary goal of increasing limited liability is to reduce systemic risk, ${ }^{165}$ shadow banking firms designated as systemically important financial institutions (SIFIs) under the DoddFrank Act ${ }^{166}$ should at least be included in the redesign of limited liability. Other shadow banking firms should be considered for inclusion, however. Being relatively small, many shadow banking firms might avoid SIFI designation; nonetheless, they could be systemically important if, for example, their solvency or liquidity is highly correlated with that of other shadow banking firms.

2. The term "investor-managers" means equity investors who also have significant power to control the firm's actions. ${ }^{167}$ To minimize discouraging investment, the redesign should apply only to the subset of those equity investors who are entitled to a significant share of their firm's profits, since they are the ones who have strong incentives to take risks with their firms. ${ }^{168}$

3. Limited liability should be increased sufficiently to motivate investormanagers to monitor and guard against systemic risk. This could be done by increasing such liability to a multiple of the original investment, discussed below.

4. Any such increase in limited liability should be constrained so as not to unduly discourage investment. ${ }^{169}$ This could be done by setting a cap on liability, such as restricting liability to a small multiple of the original investment. Recent scholarship suggests that double liability might represent a good balance. ${ }^{170}$ What actually represents a good balance-e.g., a multiple of two (double liability), or less than two (e.g., 1-1/2 liability), or more than two-will ultimately be an empirical question.

5. Any increase in limited liability should minimize costs by discouraging the need to engage in cross-investor monitoring. ${ }^{171}$ Increasing such liability to a multiple of the original investment (such as double liability) would

164 See supra notes 3-5 and accompanying text.

165 See supra notes 97-99, 108-26 and accompanying text.

166 See supra note 124.

167 See supra notes 142-43 and accompanying text.

168 See supra notes 112-14 and accompanying text.

169 See supra notes 134-37 and accompanying text.

170 See supra note 75 and accompanying text.

171 See supra notes 90, 139 and accompanying text. 
satisfy this requirement because any given investor-manager's liability would be independent of the liability of other investors.

6. Because the law does not currently have an effective mechanism to internalize systemic externalities, ${ }^{172}$ an increase in limited liability would not, by itself, necessarily expose investor-managers to systemic costs for which they should be responsible. To mitigate systemic risk-taking, any increase in limited liability should be coupled with a mechanism to internalize those costs. One such mechanism could be a privatized systemic risk fund into which systemically risky shadow banking firms would be required to contribute. Investor-managers would thus be liable, up to their liability cap, for their firm's insufficiency in making contributions. ${ }^{173}$ Creating and maintaining such a fund would have its own costs and political considerations.

7. To solve the collective action problem of cross-border capital flight (i.e., that increasing liability in any given jurisdiction could drive investors to firms in other jurisdictions) - or at least the fear of capital flight ${ }^{174}$-federal law, rather than state law, could be used to increase limited liability in the United States. ${ }^{175}$ Some form of cross-border cooperation would be needed, however, to help mitigate the problem of international capital flight. ${ }^{176}$

172 See supra notes 126-32 and accompanying text.

173 See supra notes 157-62 and accompanying text.

174 See supra notes 55, 145-48 and accompanying text.

175 See supra note 147 and accompanying text.

176 See supra note 148 and accompanying text. 